\title{
Cellular and Molecular Mechanisms of Anti-Phospholipid Syndrome
}

\author{
Marko Radic ${ }^{1 *}$ and Debendra Pattanaik ${ }^{2}$ \\ 'Department of Microbiology, Immunology and Biochemistry, University of Tennessee Health Science Center, Memphis, TN, \\ United States, ${ }^{2}$ Division of Rheumatology, Department of Medicine, University of Tennessee Health Science Center, \\ Memphis, TN, United States
}

\section{OPEN ACCESS}

Edited by:

Pier Luigi Meroni,

Università degli Studi di Milano,

Italy

Reviewed by:

Anisur Rahman,

University College London,

United Kingdom

Paola Migliorini,

Università degli Studi di Pisa,

Italy

${ }^{*}$ Correspondence: Marko Radic

mradic@uthsc.edu

Specialty section:

This article was submitted to Inflammation,

a section of the journal

Frontiers in Immunology

Received: 09 March 2018

Accepted: 18 April 2018

Published: 07 May 2018

Citation:

Radic M and Pattanaik D (2018) Cellular and Molecular Mechanisms of Anti-Phospholipid Syndrome.

Front. Immunol. 9:969. doi: 10.3389/fimmu.2018.00969
The primary anti-phospholipid syndrome (APS) is characterized by the production of antibodies that bind the phospholipid-binding protein $\beta 2$ glycoprotein I ( $\beta 2 \mathrm{GPI}$ ) or that directly recognize negatively charged membrane phospholipids in a manner that may contribute to arterial or venous thrombosis. Clinically, the binding of antibodies to $\beta 2 \mathrm{GPI}$ could contribute to pathogenesis by formation of immune complexes or modification of coagulation steps that operate along cell surfaces. However, additional events are likely to play a role in pathogenesis, including platelet and endothelial cell activation. Recent studies focus on neutrophil release of chromatin in the form of neutrophil extracellular traps as an important disease contributor. Jointly, the participation of both the innate and adaptive arms of the immune system in aspects of the APS make the complete understanding of crucial steps in pathogenesis extremely difficult. Only coordinated and comprehensive analyses, carried out in different clinical and research settings, are likely to advance the understanding of this complex disease condition.

Keywords: anti-phospholipid syndrome, systemic lupus erythematosus, neutrophil extracellular traps, autoantibodies, beta2 glycoprotein I, phospholipids, coagulation protein disorders, thrombosis

\section{INTRODUCTION}

Anti-phospholipid syndrome (APS) and systemic lupus erythematosus (SLE) are two autoimmune disorders that have puzzled researchers for decades (1-3). The two disorders have a range of shared clinical manifestations and can occur together in the same individual, often after a period of exclusive APS or SLE manifestations. Therefore, it is possible to consider them as different points of departure along a continuum of potential clinical manifestations. According to that view, secondary APS may arise as consequence of a worsening overall disease presentation. Antibodies to phospholipids (PL) and DNA are emblematic of the two disorders. Here, we highlight similarities and differences between the two disorders (Figure 1) in order to argue that discoveries across related research fields will help advance understanding of the unifying factors in their pathogenesis and help explain their notable overlap in presentation. Below, we raise important and as yet unanswered questions that address the relation between external stimuli or insults to the immune system, the diverse and often unique immune responses to these stimuli, the characteristics of the resulting antigen specificities, and the initial break in tolerance mechanisms. Importantly, we summarize how autoantibody binding shapes the observed pathology of the disorders and how it informs the search for new therapies.

A striking feature of APS and SLE is the nature of the defining antigens. Both DNA and PL are among the most abundant and pervasive antigens in the body and both are highly negatively charged. It is not surprising that charge interactions play an important role in DNA/PL recognition and that antibodies with positively charged residues in the complementarity determining regions are positively 


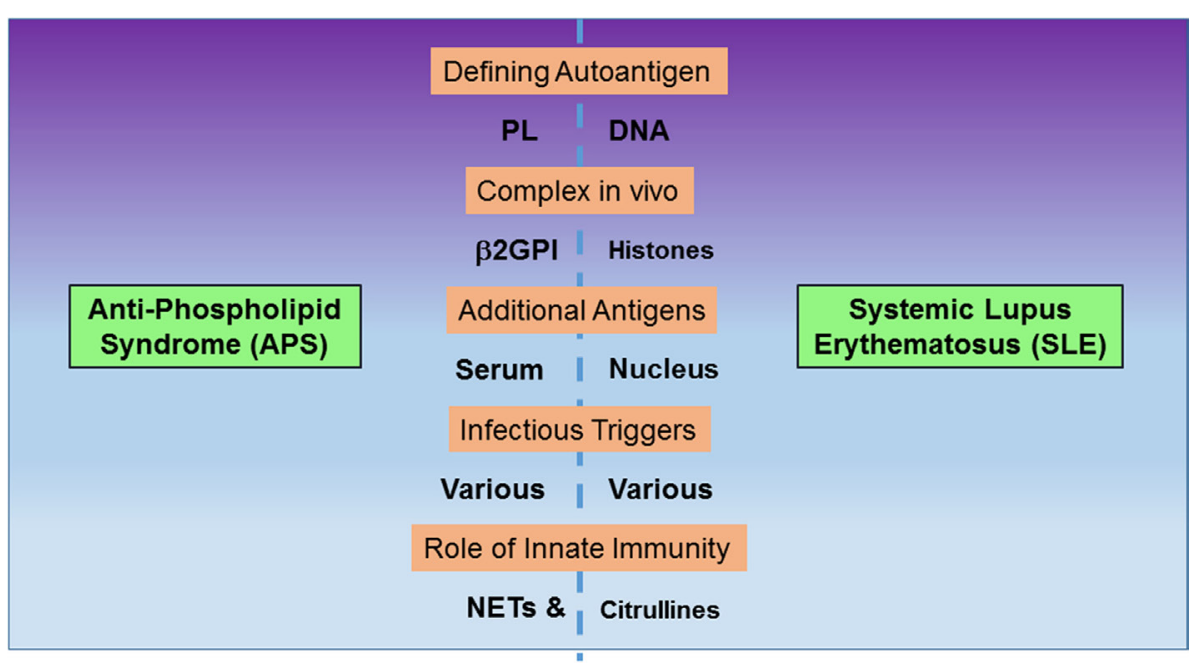

FIGURE 1 | Comparison of features between anti-phospholipid syndrome (APS) and systemic lupus erythematosus (SLE). The two autoimmune disorders exhibit autoantibodies to negatively charged, non-protein antigens, phospholipids (PL), and DNA. However, autoantibodies also recognize complexes between PL and $\beta 2 \mathrm{GPI}$ or DNA and histones, respectively. Additional autoantibody targets include other serum proteins in APS and nuclear proteins in SLE. Both disorders are potentially triggered by infections, and innate immunity contributes to pathogenesis, as neutrophil extracellular traps (NETs) form integral components of thrombi in vivo and citrullinated histones are prominent anti-citrullinated protein autoantibodies.

selected to recognize both autoantigens $(4,5)$. In fact, the similar charge distribution is, in part, one reason for the observed crossreactivity between anti-PL and anti-DNA antibodies (6). Both DNA and the negatively charged PL are usually shielded from the humoral immune system by the cell membrane but become externalized during cell death on the surface of apoptotic cells $(6,7)$. In other forms of cell death, such as necrosis or NETosis, a recently defined neutrophil death (8) that involves the dispersal of chromatin in the form of neutrophil extracellular traps (NETs), DNA and negatively charged PL are also likely to be externalized and to become accessible to antibodies. Therefore, it is reasonable to conclude that cell death contributes antigens that stimulate the anti-self response in APS and SLE (9).

Additional features of both autoantigens include the fact that they exist as multi-molecular complexes in vivo. As is the case for most charged macromolecules in the body, both DNA and PL are neutralized by basic proteins that carry countercharges, such as the positively charged histones for DNA and $\beta 2$ glycoprotein I $(\beta 2 \mathrm{GPI})$ for PL. Interestingly, DNA and PL are also recognized by other abundant serum proteins including C-reactive protein, serum amyloid protein, collectins, and pentraxins (9). These proteins contribute to scavenge and clear apoptotic cell debris and possibly the remnants of other forms of cell death. More recently, $\beta 2 \mathrm{GPI}$ was observed to bind microvesicles and thus potentially participate in the signal transduction mediated by these subcellular particles (10). By several pathways, $\beta 2 \mathrm{GPI}$ contributes to the physiological clearance of dead cells (11) and it may serve to restore homeostasis following an insult to the body in the form of an infection or other tissue injury.

Depending on the precise molecular interactions, antibody binding to $\beta 2 \mathrm{GPI}$ could either assist in the clearance of dead cells or derail the normal course of apoptotic cell removal. Obstructive binding of antibodies to $\beta 2 \mathrm{GPI}$, therefore, could delay clearance of cell debris and increase the risk of apoptotic cell dispersal. In that way, anti- $\beta 2$ GPI could promote the broader autoantibody reactivity to autoantigens displayed on apoptotic cells, such as DNA and chromatin. The binding of anti- $\beta 2$ GPI to $\beta 2$ GPI may interfere with apoptotic cell recognition and clearance, thus favoring the generation of autoantibody specificities that are indicative of lupus or related autoimmune diseases. Because APS shares certain vascular manifestations not only with Wegener's granulomatosis and polyarteritis nodosa but also other vasculitis conditions (12), a deeper insight into the autoreactivity in APS may shed light on the mechanisms shared by this broad constellation of autoimmune disorders. Detection of anti-PL prior to diagnosis in subsequent patients with SLE is associated with more severe SLE manifestations, including renal disease, thrombocytopenia, and thrombosis (13). Experimental support for the initiating role of anti- $\beta 2 \mathrm{GPI}$ antibodies in a broader autoimmune response derives from mice immunized with human $\beta 2 \mathrm{GPI}$ in lipopolysaccharide (LPS) adjuvant, which exhibit delayed clearance of apoptotic cells and, over time, an increase in autoantibody binding to nuclear autoantigens (14). Importantly, T cell recognition of $\beta 2 \mathrm{GPI}$ peptides may contribute to epitope spread in mice and humans that may include typical SLE autoantigens (15).

An intriguing open question is whether infections induce anti-DNA and anti-PL antibodies. This may be the case because microbes and the host may share cross-reactive antigens; APS was initially discovered due to a false-positive test for syphilis (16). Alternatively, the infectious process may induce the exposure of self-molecules on the cell surface. In the latter case, posttranslational modifications (PTM) that characterize the innate response to infections may determine the reactivity profile of the induced autoantibodies. Such is indeed the case, as autoantibodies frequently target the specific PTM that arise during an immune response to infections. One notable example is the induction of 
autoantibodies to self-antigens that contain citrulline residues (17). Citrullines are produced by peptidylarginine deiminases (PADs) that convert certain arginine residues in proteins to citrulline residues (18) and become activated in granulocytes that are exposed to infectious or inflammatory stimuli (19). In fact, citrullinated histones are integral components of NETs. Notably, autoantibodies to citrullinated self-proteins are diagnostic for a range of autoimmune disorders, including SLE (20), and NETs appear to play a key role in the formation of thrombi (21-23). Additional PTM may result from infections and affect the binding of APS antibodies to $\beta 2 \mathrm{GPI}$, as circulating levels of oxidized $\beta 2 \mathrm{GPI}$ correlate with the appearance of anti- $\beta 2 \mathrm{GPI} \operatorname{IgG}(24)$.

An additional mechanism may link $\beta 2 \mathrm{GPI}$ to the pathogenesis of thrombotic events in APS. This may result from the direct binding of $\beta 2$ GPI to endothelial cells and the activation of inflammatory receptors on these cells (25). The direct binding of $\beta 2 \mathrm{GPI}$ to endothelial cells, a process that is aided by TLR4, directly activates endothelia. Similarly, Laplante et al. (26) showed in a carotid artery injury model that anti- $\beta 2 \mathrm{GPI}$ activation of endothelial cells is dependent on TLR4. The binding of $\beta 2$ GPI to TLR4 is enhanced by LPS and may reflect a possible scavenging of LPS. Conversely, anti- $\beta 2$ GPI antibodies enhance the production of pro-thrombotic and pro-inflammatory responses in blood vessels, a mechanism that, in part, is driven by activation of the nuclear factor $\kappa \mathrm{B}(\mathrm{NF}-\kappa \mathrm{B})$ and AP1 signaling pathways (27). In the following sections, we focus on APS and leave a more detailed comparison to SLE for a separate venue.

\section{THE FUNDAMENTALS OF APS}

Anti-phospholipid syndrome is characterized by vascular thromboembolism, miscarriages, and other pregnancy comorbidities (1). The presence of anti-PL, which include anti-cardiolipin (anti-CL) anti- $\beta 2$ GPI antibodies, and lupus anticoagulant (LA), are the sine qua non for the diagnosis of APS (28). Vascular thrombosis, which can affect venous, arterial, or small blood vessels, is identified by histopathologic or imaging analysis. These antibodies are essential for the diagnosis and likely to play a pathogenic role in various disease manifestations (29). Thrombotic events in APS are rarely accompanied by histological evidence of vessel wall inflammation, yet many APS patients have underlying systemic autoimmune disease (30). APS pathogenesis clearly involves inflammatory pathways in endothelial cells, monocytes, and neutrophils and a variety of intercellular interactions promotes disease progression.

Anti-phospholipid syndrome-associated manifestations may include thrombocytopenia, livedo reticularis, skin ulcers, cardiac valve and kidney damage, pulmonary hemorrhage, and certain neurological manifestations (31). Patients experiencing these manifestations generally do not improve with anticoagulation therapy, suggesting that additional pathophysiologic processes may cause these outcomes of thromboembolism.

Initially, anti-PL antibodies were thought to bind directly to PL but later it was found that anti-PL may recognize negatively charged PL indirectly via PL-binding plasma proteins $(32,33)$. Anti-PL antibodies are quite heterogeneous and react with PL, PL-binding proteins, and their complexes (33). $\beta 2 \mathrm{GPI}$ is the main binding cofactor of these antibodies (34) and detection of anti- $\beta 2$ GPI has the greatest clinical significance (33). The analysis of antibody binding to $\beta 2 \mathrm{GPI}$ must take into account that $\beta 2 \mathrm{GPI}$ consists of five independently folded domains, including domain V, which resembles a "hook" and interacts with the PLs in the cell bilayer, and, at the opposite end, domain I, which is recognized by most clinically relevant antibodies in APS (35).

Depending on the redox state of the extracellular milieu, domains I and V expose different epitope surfaces for antibody binding. A tight interaction between domains $\mathrm{I}$ and $\mathrm{V}$, which defines the circular form of $\beta 2 \mathrm{GPI}$ in vivo, shields various epitopes on domain I. The dissociation between the two domains gives rise to the linear, fishhook-like structure of $\beta 2 \mathrm{GPI}$ in which the domain I epitopes are exposed (36). Cysteine residues at positions 288 and 326 of domain $\mathrm{V}$, which either remain as free thiols or form a disulfide bond, control the conversion between the two alternative in vivo conformations. In the plasma of healthy individuals, $\beta_{2} \mathrm{GPI}$ occurs in the free thiol form, which folds into a ring configuration and blocks antibody access to the principal domain I epitopes (37). Oxidative stress unfolds the ring conformation of $\beta 2 \mathrm{GPI}$, exposing the normally shielded antigenic determinants of domain I, which form epitopes for pathogenic antibodies $(36,38)$. This form inserts with domain $\mathrm{V}$ into the cell bilayer of anionic PL. Raimondo et al. determined a strong positive correlation between IgG anti-domain I and the proportion of oxidized $\beta 2 \mathrm{GPI}$, but not with IgM or IgA antidomain I (24). This observation suggests that either anti-domain I IgG stabilizes the extended, oxidized form of $\beta 2 \mathrm{GPI}$ or that chronic inflammatory conditions lead to an abundance of oxidized $\beta 2 \mathrm{GPI}$ that stimulates the production of anti-domain I IgG.

Other potential antigen targets include phosphatidylserine, tissue plasminogen activator, plasmin, thrombin, prothrombin, antithrombin III, activated protein C, and annexin V (33). The diversity of potential antigens argues for the existence of "seronegative" APS and some investigators have disputed the primary significance of anti- $\beta 2$ GPI antibodies (39). Indeed, some cofactor independent antibodies can induce thrombus formation in a mouse model (40). Overall, autoantibodies in APS, as the disorder itself, are thought to arise due to a pernicious interaction between environmental factors and increased genetic predisposition to the disease (41).

There is no general agreement on the mechanisms that contribute to thrombotic complications in APS (42). Inconsistencies that prevent a consensus from emerging are: a. the differences between patient populations used to isolate the autoantibodies, b. the specificity of the antibodies used, and c. the experimental model in which the antibodies are tested (43). Anti-PL antibodies increase the risk of thrombosis through different mechanisms that go beyond a simple dysregulation of coagulation pathways (44). It is likely that mechanisms other than simple vascular thrombosis contribute to various APS manifestation. The fact that thrombotic events occur sporadically in spite of persistently high level of anti-PL antibodies suggests that factors in addition to anti-PL antibodies are required for thrombosis to arise (45).

\section{GENETIC FACTORS PREDISPOSING TO APS}

A genetic basis for anti-PL antibodies was suspected by Harvey and Shulman from their finding of familial clustering of false-positive 
tests for syphilis (46). Anti-CL antibodies occur more frequently in first-degree relatives of SLE or primary APS patients than in unrelated control individuals, indicating that a genetic susceptibility favors the expression of anti-PL. Extended kinships with elevated expression of anti-PL were analyzed with regard to APS clinical presentation and provided evidence for a familial form of APS $(47,48)$. In another study, Goel et al. examined possible modes of genetic inheritance and noted the potential involvement of candidate genes. Their study, which involved 30 family members of APS patients, failed to confirm the contribution of several candidate genes to the disorder (49).

The combination of HLA-DQw7 (HLA-DQB1*0301) with HLA-DR4 or HLA-DR5 was significantly elevated in patients with SLE and LA as compared to 139 race-matched controls (50). Patients also expressed other HLA-DQB1 alleles from which the authors deduced a shared amino acid sequence, TRAELDT, which they proposed to constitute a potential autoantibody epitope (50). In another study, DR4 and DRw53 occurred with increased frequency in patients with primary APS (51), and a study of 577 European SLE patients presenting with anti-CL antibodies found a positive association with $\mathrm{DPB1}^{\star} 1501$ ( $P$ value: 0.005 , OR 7.4), and $\mathrm{DPB} 1^{\star} 2301$ ( $P$ value: 0.009 , OR 3.3 ). Anti $\beta_{2} \mathrm{GPI}$ antibody was positively associated with DPB1*0301 ( $P$ value: 0.01 , OR 1.9$)$, and DPB1*1901 ( $P$ value: 0.004 , OR 8.1). The authors conclude that the genetic risk of anti-PL antibodies-along with other clinical manifestations of APS - may be increased in SLE patients who are positive for certain HLA-DPB1 alleles (52). In Japanese patients with APS secondary to SLE, DRB ${ }^{\star} 09$ has been linked to anti-CL (53). In Caucasians and Mexican Americans, HLA-DQ8 $\left(\mathrm{DQB} 1^{\star} 0302\right)$ and related HLA-DR4 haplotypes may predispose to anti- $\beta 2 \mathrm{GPI}$, whereas British patients with primary APS show an association between anti- $\beta 2$ GPI and the HLA-DRB1 ${ }^{\star} 1302$ and DQB1 ${ }^{\star} 0604 / 0605$ (50, 54-56). Furthermore, C4A or C4B null alleles may associate with the presence of anti-CL antibodies in African-American populations (57). Notably, a polymorphism in domain V of $\beta 2 \mathrm{GPI}$ is observed more frequently in APS patients with anti- $\beta 2$ GPI antibodies than in matched controls $(58,59)$. Genetic polymorphisms have also been linked to thrombosis in APS patients. These polymorphisms range from variants of tissue factor (TF) pathway inhibitor, type-I plasminogen activator inhibitor, tumor necrosis factor $\alpha$ (TNF $\alpha)$, annexin A5, p-selectin, p-selectin glycoprotein ligand-1 (PSGL-1), platelet Fc receptor IIa, platelet glycoproteins GP Ia/IIa and GP IIb/IIIa, thrombomodulin, factor XIII, methylenetetrahydrofolate reductase, toll-like receptor 4, and CD40 (33). In view of the many diverse genetic factors that predispose to APS, a picture of a delicate balance of steps in the coagulation pathway emerges, in which a disequilibrium at any one point may tilt the equation toward thrombosis.

\section{GENETIC ANALYSIS IN MODEL SYSTEMS}

The first evidence that genetics contributes to pathogenic anti-PL in APS came from studies in mice. The spontaneous production of pathogenic IgG anti-CL that depend on $\beta 2 \mathrm{GP}$ for binding to CL occurs in NZW x BXSB F1 (W/B F1) male mice (60). W/B F1 mice develop autoantibodies to negatively charged
PLs, including phosphatidylserine and phosphatidylinositol, and generate circulating immune complexes, which ultimately result in glomerulonephritis. The pathogenic anti-CL antibodies preferentially use certain $\mathrm{V}_{\mathrm{H}}$ and $\mathrm{V}_{\mathrm{K}}$ genes, whereas nonpathogenic anti-CL antibodies use more heterogeneous $\mathrm{V}$ genes (61). Microsatellite markers have enabled genetic analysis of BXSB alleles that affect production of anti-CL and anti-platelet antibodies, cytopenia, and coronary artery disease in W/B F1 male offspring (62). Disease was dependent on two dominant alleles that acted as complementary genes and localized to separate chromosomes. Anti-platelet antibodies and thrombocytopenia were genetically and mechanistically linked but anti-CL and myocardial infarction depended on independent genetic contributions, suggesting that genetics of APS is complex (62). In another mouse model, the MRL-lpr/lpr mice, the specificity of a monoclonal anti-CL was shown to depend on stochastic events, including somatic mutations in the $\mathrm{V}_{\mathrm{H}}$ gene, indicating that failure in peripheral tolerance mechanisms followed by antigen-driven selection and clonal expansion contribute to this autoreactivity (61).

Papalardo et al. demonstrated that pathogenic anti-PL and clinical manifestations of APS depend, in part, on particular MHC-II alleles (63). Wild-type mice, or mice that expressed human DR4, DQ6, or DQ8 genes, but not MHC-II knockout mice, produced thrombogenic anti-PL and TF after immunization with human $\beta 2 \mathrm{GPI}$. In addition, in wild-type C57BL/6J mice, anti-CL antibodies were not $\beta 2$ GPI dependent and instead showed diminished binding to CL in the presence of the $\beta 2 \mathrm{GPI}$ cofactor (64). This study suggested the importance of certain MHC class II haplotypes in determining the levels of anti-PL antibodies and their pathogenic capacity.

\section{INFECTIONS AS APS TRIGGERS}

Infections are potential inducing factors for the production of autoantibodies in APS (65). Various infectious agents have been linked to the pathogenesis of APS but a definitive proof is still lacking. BALB/c mice infected with Haemophilus influenzae, Neisseria gonorrhoeae or immunized with tetanus toxoid developed antibodies to the TLRVYK peptide and anti- $\beta 2$ GPI reactivity (66). Moreover, naïve mice developed features of classic APS after infusion of these antibodies. The hexapeptide TLRVYK is a component of proteins expressed by these microbes and is also recognized by a pathogenic monoclonal anti- $\beta 2 \mathrm{GPI}$ antibody, suggesting the role of molecular mimicry as the potential cause of development of APS. A literature review revealed that, in people, the development of APS may be linked with HIV, HTLV, HBV, $\mathrm{HCV}$, parvovirus B19, and varicella zoster virus infections (67). Infectious agents may induce autoantibodies through various mechanisms. Possible mechanisms include molecular mimicry, increased secretion of cytokines and chemokines, selective activation or depletion of lymphocyte populations, and exposure of cryptic epitopes due to the induction of cell death $(68,69)$.

Certain infectious agents may also directly affect the immunogenicity of $\beta 2 \mathrm{GPI}$. Patients with APS exhibit a significant increase in oxidized $\beta 2$ GPI (70). Infectious agents could generate conditions that favor reactive oxygen and nitrogen species that may 
enhance $\beta 2$ GPI oxidation and autoantibody production (71). Medications, such as chlorpromazine, amoxicillin, quinine, chlorothiazide, and propranolol, in addition to oral contraceptives, alpha-interferon and infliximab, may promote the expression of anti-PL antibodies (72). The preferred interpretation of these results is that medications may bind to self-antigens and create new binding determinants, so-called neo-antigens, which may induce autoantibody production (73).

\section{ENDOTHELIAL AND PLATELET CONTRIBUTIONS}

Cell activation is a key element in the increased thrombotic response (42). Some authors suggested endothelial cells are critical in APS-associated thrombosis (74), whereas others proposed a paradigm shift, which favored a central role of platelets (75). It is also possible that endothelial cells, directly or indirectly, promote the release of pro-thrombotic microparticles (76). This promises to be an exciting area of research in the near future.

\section{INNATE IMMUNITY AND NETS}

The cellular immune response to infections may be directly responsible for generating conditions that are favorable for the initiation of APS. Although lymphocytes, monocytes, and platelets receive much deserved attention for their role in the pathogenesis of APS, neutrophils contribute in a unique and relevant manner to the development of APS (77). Neutrophils are by far the most abundant leukocyte in the blood and they rapidly respond to inflammatory stimuli (78). Circulating neutrophils attach to activated endothelia, which express adhesion molecules, and invade tissues that harbor infectious organisms or exhibit other signs of inflammation. The neutrophils have alternative mechanisms to combat microbes, including phagocytosis and granule discharge (79). An intriguing antibacterial mechanism is the release of NETs. NETs consist of nuclear chromatin that escapes from the confines of the nucleus and disperses as an amorphous lattice from the cell. The NET fibers attach to various components of neutrophil granules that help to enhance the bactericidal properties of the lattice (80).

Neutrophil extracellular traps are important in the context of APS because APS patient neutrophils are prone to spontaneous NET release (22), and thrombi incorporate NET-derived materials $(21-23,81)$. In vitro, neutrophils respond to incubation with anti- $\beta 2$ GPI antibodies by an intensified NET release (22). In animal models, inhibitors of NET release show promise in reducing thrombus formation, and mice deficient for PAD4, the enzyme that deiminates histones and promotes DNA unraveling in NETs, are resistant to pro-thrombotic stimuli (82). A recent study identified PSGL-1, a neutrophil protein that mediates adhesion to endothelia, as an important regulator of the prothrombotic functions of neutrophils, and small molecules that target this protein may hold the key to new therapies for APS (83). Clearly, neutrophil biology in the context of APS warrants further attention and is likely to reveal new and exciting implications for APS pathogenesis.

\section{MECHANISMS OF ANTIBODY-MEDIATED THROMBOSIS}

The pathogenic mechanisms that contribute to thrombus formation have been examined using both in vitro and in vivo models of APS. Anti-PL antibodies increase thrombus formation in the venous and arterial circulation (84-86). Infusion of autoantibodies from APS patients to mice with injured blood vessels potentiates thrombus formation in a way that suggests a pathogenic role for APS antibodies. Anti- $\beta 2$ GPI IgG autoantibodies, but not IgG depleted of anti- $\beta 2$ GPI reactivity, or normal human IgG, increase thrombus size in a dose-dependent manner (87). Administration of human anti-PL IgG along with LPS causes micro thrombosis in rat model (88). In contrast, infusion of anti-PL antibodies alone into the experimental animal models does not result in spontaneous thrombotic complications, thus suggesting the requirement for priming with a small vascular injury or injection of a low dose of LPS. This is in line with the "Two Hit Hypothesis" (89) that was proposed to account for the clinical observation that, despite the continued presence of anti-PL, thrombotic events are rare. According to the two-hit hypothesis, the anti-PL antibody induces a thrombophilic state, but requires a second condition (e.g., an infection) for clotting to take place. Infusion of purified anti-PL antibodies with or without dimeric $\beta 2 \mathrm{GPI}$ alters endothelial adhesion molecule expression and leads to a perturbation of vascular function associated with TLR 2 and TLR4 signaling and the upregulation of nitric oxide and TF expression (86, 90-93). As microbes and microbial products signal through TLRs, so it is possible that an infection and anti-PL signaling through the TLRs can additively increase the risk of thrombosis. Thus, infections or inflammation may increase the expression of the anti-PL target or enhance the exposure of previously hidden epitopes (37). None the less, the "two hit hypothesis" does not conform well with the obstetric manifestations of APS, where the anti-PL is the single factor that leads to the increased risk of venous thromboembolism during pregnancy (94), although pregnancy itself may be viewed as the "second hit."

A recent systematic review and meta-analysis found that LA and anti-CL antibodies are associated with an increased risk of venous thromboembolism $[\mathrm{OR}=6.14$ (CI 2.74; 13.8) and $\mathrm{OR}=1.46$ (CI 1.06; 2.03), respectively] (95). All three antibodies show a significant association: ORs for LA, anti-CL, and anti32 GPI were 3.58 (CI 1.29-9.92), 2.65 (CI 1.75-4.00), and 3.12 (CI 1.51-6.44), respectively, with arterial thrombosis (95). Anti- $\beta 2$ GPI antibodies with LA activity are considered the main culprits for the thromboembolic complications in APS (96). A subgroup of anti- $\beta 2 \mathrm{GPI}$ antibodies that bind the epitope comprising Gly40-Arg43 (G40-R43) in domain I were shown to act as LA and correlate strongly with thrombosis $(34,97)$.

Subjects positive for LA, high titers of anti-CL, and anti- $\beta 2 \mathrm{GPI}$ antibodies (called "triple positives"), more than any other anti-PL profile, have high risks for thrombosis and pregnancy morbidity (98). The risk of recurrent thrombosis in triple-positive patients was around 30\% over a 6 -year follow-up period. Triple-positive anti-PL patients usually have high titers of antibodies to the major $\beta 2$ GPI epitope on domain I (99). Thus, anti-domain I $\beta 2 G P I$ autoantibodies, which frequently present in triple anti-PL-positive 
patients, confer LA activity, associate with the highest risk of thrombosis (100), predispose to both thrombosis and pregnancy loss (100), and promote thrombosis in mouse models (101). Clearly, a detailed profile of anti- $\beta 2$ GPI antibody specificity and avidity may be useful as a risk stratification resource in the clinic (30).

\section{PREGNANCY LOSS}

Intraplacental thrombosis leading to poor vascular supply to placenta was thought to be the major pathogenic mechanism but is certainly not the universal mechanism of fetal loss in APS. Other anti-PL antibody-induced pro-inflammatory, complementmediated pathways, and defective placentation might be playing a role (94). Passive transfer of anti-PL antibodies causes fetal loss due to placental thrombosis and also inhibits trophoblast and decidual cell function in vitro and in animal models (102). Anti-PL antibodies, in particular anti- $\beta 2$ GPI antibodies, may compete with the anticoagulant annexin A5 for binding to trophoblast and endothelial cells, thus increasing the risk of placental thrombosis (103). However, the in vitro studies may be challenged by the fact that microscopic analysis of tissues from miscarried fetuses or placentas of women with APS rarely show thrombosis (104). This could be related to the timing of the examination of the placental samples, as many of the events may occur early in the pregnancy, and later only residual damage may remain (94).

Complement products, TNF $\alpha$ and CC chemokines, along with other pro-inflammatory mediators, contribute to antiPL-induced fetal loss in animal models (105). Injection of human anti-PL IgG into naïve mice following embryo implantation caused placental inflammatory changes. Human IgG and mouse complement deposited along the decidua, and a transient increase in blood TNF $\alpha$ coincided with neutrophil infiltration into the tissues (106-108). Studies of animal and human placenta indicate that complement activation by anti-PL may be major contributor to the recurrent pregnancy loss in APS (107). The complement system contributes to fetal loss in the mouse model as either complement inhibition or deficiency of complement components protects the mouse from fetal loss (109).

Complement activation by anti-PL antibodies, which bind decidua and placenta preferentially, may involve the classical and, perhaps, lectin pathways. In the process, potent anaphylatoxins (C3a and C5a) may be generated, leading to the recruitment of inflammatory cells. Further activation of the alternative pathway creates a localized pro-inflammatory amplification loop, which enhances $\mathrm{C} 3 \mathrm{a}$ activation and deposition and generates additional anaphylatoxins, thus attracting additional inflammatory cells to the placenta (110). Inflammatory tissue injury is probably mediated by TNF- $\alpha$, which increases in murine decidua after exposure to anti-PL (108). Additionally, the therapeutic effect of heparin can be traced to inhibition of complement rather than inhibition of coagulation (111). Treatment with unfractionated or low molecular weight heparins protects against pregnancy loss induced by anti-PL antibodies, whereas use of plain anticoagulants, such as hirudin or fondaparinux that have no anti-complement effects, do not protect from pregnancy loss (110).

Nonetheless, investigations have not gathered conclusive evidence to support the pathogenic roles of inflammation and complement deposition in obstetric complications (112). There was no evidence of inflammation in placenta in a mouse model of anti-PL antibody-induced fetal loss following IV administration of human anti-PL IgG before implantation (113). Data from in vivo animal models may be inconclusive because of the fact that observations cannot be continuous during the pregnancy and depend on the time chosen for the infusion of the putative pathogenic autoantibodies (94).

Additional mechanisms may be involved in anti-PL-induced fetal loss. Binding of $\beta 2 \mathrm{GPI}$-dependent antibodies to human trophoblasts inhibits cell proliferation and syncitia formation, decreases production of chorionic gonadotrophin, perturbs secretion of growth factors, and induces apoptosis (114). Moreover, $\beta 2 \mathrm{GPI}$-dependent antibodies may impair the expression of cell adhesion molecules, such as integrins and cadherins, in trophoblastic and decidual cells that perturb function at the maternal side of the placenta (115). Defects in endometrial differentiation, including the impaired expression of complement decay-accelerating factor (also known as CD55), arise and are evident on endometrial biopsies. Such alterations may compromise implantation, if they occur at or before conception. After conception, endometrial defects are likely to predispose to complement-mediated pregnancy failure (116).

Anti-PL greatly increase the risk of preeclampsia. A recent study concluded that anti-PL act, in part, by compromising the mitochondria in the syncytiotrophoblast and increasing the amount of mitochondrial DNA released via placental vesicles (117). The vesicles may increase the risk of preeclampsia because the mitochondrial DNA, which is recognized as a DAMP by TLR9 , may activate endothelial cells. If this concept is confirmed, then pharmaceutical intervention aimed at reducing placental vesicles and the signaling by mitochondrial DNA through TLR-9 may have the potential to lessen the adverse consequences of anti-PL in pregnancy (117).

\section{IMMUNE SIGNALING PATHWAYS}

It is not clear how binding of anti-PL antibodies to endothelial cells may lead to cell activation, as no clear cellular activation pathway has been identified. Candidate interactions include the binding of the anti-PL- $\beta 2$ GPI complex to TLR 2 or 4 , the binding of annexin A2, or mediation of the low density lipoprotein receptorrelated protein 8 , followed by activation of a signal transduction pathway inside the cells. In each case, a more pro-thrombotic cell phenotype may be the outcome (42). Activation of individual or sets of receptors are possible (118). A recent study has shown that antibody uptake is essential for anti-PL antibody-induced cellular signaling (119). MyD88 and TRAF6-dependent signaling, as well as NF- $\kappa \mathrm{B}$ and p38 mitogen-activated protein kinase signaling, may be involved downstream from anti-PL binding to $\beta 2 \mathrm{GPI}$ on the cell surface (114). However, it is not clear whether clinical manifestations differ depending on which cell signaling pathways are engaged, or whether different anti-PL subpopulations have different effects on cell activation (94).

Activation of the mechanistic target of rapamycin (mTOR) pathway plays a role in endothelial proliferation and intimal hyperplasia in anti-PL-positive patients, which leads to multiple potential 
outcomes, including micro thrombosis, peripheral ischemia, skin ulcers, diffuse alveolar hemorrhage, or anti-PL nephropathy. IgG antibodies from APS patients, when incubated with vascular endothelial cells, stimulate the mammalian/mTOR through the phosphatidylinositol 3-kinase-AKT pathway (120) leading to cell proliferation. The authors showed that sirolimus, a mTOR complex inhibitor reduced endothelial cell proliferation and vascular lesions among patients with APS nephropathy, who required transplantation, as compared with patients with anti-PL antibodies, who did not receive sirolimus. Furthermore, in vitro studies have shown that treatment of anti- $\beta_{2} \mathrm{GPI} / \beta_{2}$ GPI or APS-IgG/ $\beta_{2}$ GPI complex could markedly induce mTOR activation as well as expression of TF and IL-8 in THP-1 cells (a human monocytic cell line) or primary monocytes. The mTOR inhibitor rapamycin $(100 \mathrm{nM})$ could attenuate the elevated expression of TF and IL-8 (121).

\section{MEDICATIONS AND POTENTIAL THERAPIES}

A necessary step in anti-PL-mediated thrombosis and fetal loss seems to be the activation of complement, as discussed above. The activation of the classical complement pathway in APS-associated thrombosis is evident from mouse studies $(88,122)$. Activation of complement by anti-PL autoantibodies generates C5a, which attracts and activates neutrophils and enhances expression of TF (123). Conversely, mice treated with APS patient IgG had higher titers of anti-CL antibodies and anti- $\beta 2$ GPI leading to thrombosis; subsequently, they developed larger thrombi and higher soluble TF activity than controls. The recombinant C5 activation inhibitor rEV576 (coversin) reduced thrombus formation and suppressed TF activity from cells treated with IgG-APS $(124,125)$. The murine studies are in agreement with human studies. In a study of 186 patients, levels of fragments $\mathrm{Bb}$ and C3a were significantly increased compared to normal controls (126). APS patients who suffered from venous thromboembolism had significantly increased complement activation compared to normal controls, which Rivaroxaban effectively reduced (127). Mildly reduced complement levels (C3, C5), perhaps indicating complement consumption, occur in some APS patients (128), although this may not be a consistent feature of the syndrome (94). Supporting the role of complement, case studies indicate the benefits of C5-inhibitor eculizumab in preventing APSassociated thrombotic microangiopathy, a complication of renal transplantation, as well as for treatment of patients with acute catastrophic APS $(129,130)$.

Additional approaches have involved synthetic peptides (Figure 2). TIFI is a 20 amino acid synthetic peptide that shares similarity with the $\beta 2$ GPI PL-binding site. Administration of the peptide prevents anti-PL-mediated thrombosis in vivo, and, as expected, TIFI inhibits the binding of $\beta 2$ GPI to human endothelial cells in vitro (131). Infusions of TIFI protected pregnant mice from human anti-PL-induced fetal loss (132), thus providing evidence for the detrimental effect of $\beta 2 \mathrm{GPI}-$ anti- $\beta 2 \mathrm{GPI}$ complexes binding to trophoblasts in anti-PL-induced fetal loss (133). Similarly, the recombinant DI domain of $\beta 2 \mathrm{GPI}$, the major anti-PL antibody target in APS, could inhibit experimental thrombus development in mice infused with APS patient IgG (134). The observation that $\beta 2 \mathrm{GPI}$ binds avidly to the ApoER2 A1 domain, the main LDL binding domain 1 (92), was the impetus to construct and test the recombinant dimer of $\mathrm{A} 1$ as an effective inhibitor of the prothrombotic functions of anti- $\beta 2 \mathrm{GPI}$ antibodies in mice (135). The successful deployment of each of these three recombinant protein domains (and their variants) raises the possibility that biologic therapies based on these peptide structures (Figure 2) may be developed in the near future.

Because neutrophils likely exert a unique and important function in APS pathogenesis, a range of approaches that limit neutrophil activation and NET release may move into the spotlight as targeted treatments for patients with APS. For example, $N$-acetyl cysteine, an effective scavenger of ROS that reduces the release of NETs in vitro and inhibits mTOR in T cells, has shown promise in SLE trials (136). Similarly, inhibitors of myeloperoxidase, a granule component in neutrophils that may catalyze reactions leading to NET release, have been used in patients with vasculitis and may be considered candidates for trials in APS (137). Moreover, the specific TLR4 inhibitor, TAK-242, which acts upstream of mTOR to reduce NET release and inhibit ROS production in neutrophils, has shown potential as treatment for APS (121).

In sum, we propose that APS therapy is at the doorstep of its most exciting stage. Numerous pathogenic mechanisms have been proposed and experimentally supported, and diagnostic and prognostic measures of APS activity have improved to the point that a broad range of potential therapies have appeared

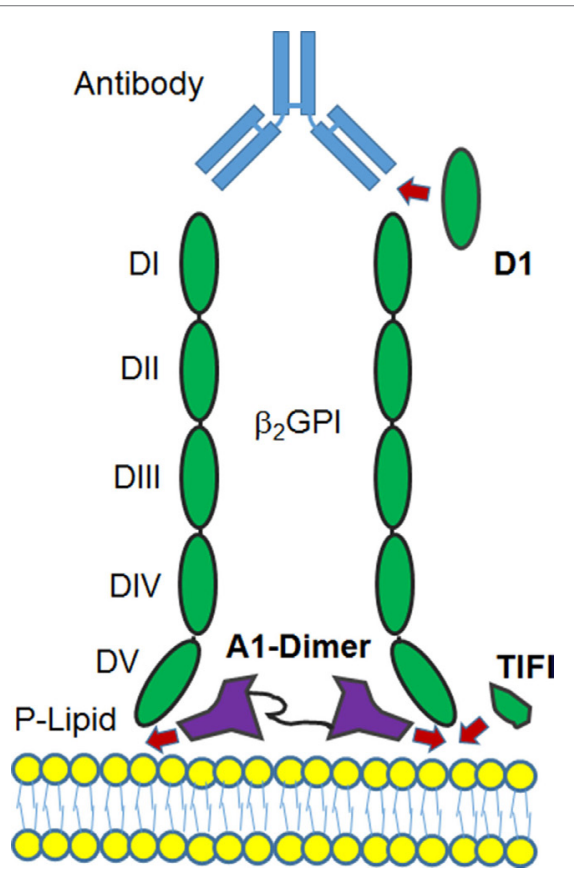

FIGURE 2 | Diagram of potential sites where binding of $\beta 2 \mathrm{GPI}$ to a phospholipid membrane may be disrupted. Recombinant versions of the D1, a portion of the DV domain (TIFI) or a dimer of the ApoER2 domain A1 are shown to indicate where the formation of the $\beta 2 \mathrm{GPI}$-anti- $\beta 2 \mathrm{GPI}$ complex at the cell surface may be inhibited for therapeutic benefit. For details, see main text. 
on the horizon and could soon advance through regulatory tests toward a safe and effective use in the clinics.

\section{AUTHOR CONTRIBUTIONS}

MR provided initial planning and wrote sections of the manuscript, edited the text, and gave final approval. DP participated in

\section{REFERENCES}

1. Levine JS, Branch DW, Rauch J. The antiphospholipid syndrome. $N$ Engl $J$ Med (2002) 346(10):752-63. doi:10.1056/NEJMra002974

2. Nambiar MP, Juang YT, Tsokos GC. Emerging concepts in the molecular pathogenesis of systemic lupus erythematosus. Arch Immunol Ther Exp (Warsz) (2002) 50(1):35-45.

3. Fischer MJ, Rauch J, Levine JS. The antiphospholipid syndrome. Semin Nephrol (2007) 27(1):35-46. doi:10.1016/j.semnephrol.2006.09.006

4. Monestier M, Kandiah DA, Kouts S, Novick KE, Ong GL, Radic MZ, et al. Monoclonal antibodies from NZW x BXSB F1 mice to beta2 glycoprotein I and cardiolipin. Species specificity and charge-dependent binding. I Immunol (1996) 156(7):2631-41.

5. Radic MZ, Mackle J, Erikson J, Mol C, Anderson WF, Weigert M. Residues that mediate DNA binding of autoimmune antibodies. JImmunol (1993) 150(11):4966-77.

6. Cocca BA, Seal SN, D'Agnillo P, Mueller YM, Katsikis PD, Rauch J, et al. Structural basis for autoantibody recognition of phosphatidylserine-beta 2 glycoprotein I and apoptotic cells. Proc Natl Acad Sci U S A (2001) 98(24):13826-31. doi:10.1073/pnas.241510698

7. Cocca BA, Cline AM, Radic MZ. Blebs and apoptotic bodies are B cell autoantigens. J Immunol (2002) 169(1):159-66. doi:10.4049/jimmunol.169.1.159

8. Brinkmann V, Reichard U, Goosmann C, Fauler B, Uhlemann Y, Weiss DS, et al. Neutrophil extracellular traps kill bacteria. Science (2004) 303(5663):1532-5. doi:10.1126/science.1092385

9. Radic M. Clearance of apoptotic bodies, NETs, and biofilm DNA: implications for autoimmunity. Front Immunol (2014) 5:365. doi:10.3389/ fimmu.2014.00365

10. Abdel-Monem H, Dasgupta SK, Le A, Prakasam A, Thiagarajan P. Phagocytosis of platelet microvesicles and beta2-glycoprotein I. Thromb Haemost (2010) 104(2):335-41. doi:10.1160/TH09-12-0849

11. Pittoni V, Ravirajan CT, Donohoe S, MacHin SJ, Lydyard PM, Isenberg DA. Human monoclonal anti-phospholipid antibodies selectively bind to membrane phospholipid and beta2-glycoprotein I (beta2-GPI) on apoptotic cells. Clin Exp Immunol (2000) 119(3):533-43. doi:10.1046/j.1365-2249. 2000.01161.x

12. Lally L, Sammaritano LR. Vasculitis in antiphospholipid syndrome. Rheum Dis Clin North Am (2015) 41(1):109-23. doi:10.1016/j.rdc.2014.09.009

13. McCain MT, Arbuckle MR, Heinlen LD, Dennis GJ, Roebuck J, Rubertone MV, et al. The prevalence, onset, and clinical significance of antiphospholipid antibodies prior to diagnosis of systemic lupus erythematosus. Arthritis Rheum (2004) 50:1226-32. doi:10.1002/art.20120

14. Levine JS, Subang R, Nasr SH, Fournier S, Lajoie G, Wither J, et al. Immunization with an apoptotic cell-binding protein recapitulates the nephritis and sequential autoantibody emergence of systemic lupus erythematosus. J Immunol (2006) 177(9):6504-16. doi:10.4049/jimmunol.177.9.6504

15. Salem D, Subang R, Okazaki Y, Laplante P, Levine JS, Kuwana M, et al. Beta2glycoprotein I-specific T cells are associated with epitope spread to lupusrelated autoantibodies. J Biol Chem (2015) 290(9):5543-55. doi:10.1074/jbc. M114.619817

16. Koike T, Sueishi M, Funaki H, Tomioka H, Yoshida S. Anti-phospholipid antibodies and biological false positive serological test for syphilis in patients with systemic lupus erythematosus. Clin Exp Immunol (1984) 56(1):193-9.

17. Muller S, Radic M. Citrullinated autoantigens: from diagnostic markers to pathogenetic mechanisms. Clin Rev Allergy Immunol (2015) 49(2):232-9. doi:10.1007/s12016-014-8459-2

18. Bicker KL, Thompson PR. The protein arginine deiminases: structure, function, inhibition, and disease. Biopolymers (2013) 99(2):155-63. doi:10.1002/ bip. 22127 the planning and writing of sections of the manuscript, edited the text, and gave final approval.

\section{FUNDING}

MR acknowledges the Lupus Research Institute and the Lupus Research Alliance for support of research in the Radic laboratory.

19. Neeli I, Khan SN, Radic M. Histone deimination as a response to inflammatory stimuli in neutrophils. J Immunol (2008) 180(3):1895-902. doi:10.4049/ jimmunol.180.3.1895

20. Dwivedi N, Radic M. Citrullination of autoantigens implicates NETosis in the induction of autoimmunity. Ann Rheum Dis (2014) 73(3):483-91. doi:10.1136/annrheumdis-2013-203844

21. Meng H, Yalavarthi S, Kanthi Y, Mazza LF, Elfline MA, Luke CE, et al. In vivo role of neutrophil extracellular traps in antiphospholipid antibody-mediated venous thrombosis. Arthritis Rheumatol (2017) 69(3):655-67. doi:10.1002/ art.39938

22. Yalavarthi S, Gould TJ, Rao AN, Mazza LF, Morris AE, Nunez-Alvarez C, et al. Release of neutrophil extracellular traps by neutrophils stimulated with antiphospholipid antibodies: a newly identified mechanism of thrombosis in the antiphospholipid syndrome. Arthritis Rheumatol (2015) 67(11) 2990-3003. doi:10.1002/art.39247

23. Martinod K, Wagner DD. Thrombosis: tangled up in NETs. Blood (2014) 123(18):2768-76. doi:10.1182/blood-2013-10-463646

24. Raimondo MG, Pericleous C, Radziszewska A, Borghi MO, Pierangeli S, Meroni PL, et al. Oxidation of beta2-glycoprotein I associates with IgG antibodies to domain I in patients with antiphospholipid syndrome. PLoS One (2017) 12(10):e0186513. doi:10.1371/journal.pone.0186513

25. Borghi MO, Raschi E, Grossi C, Chighizola CB, Meroni PL. Toll-like receptor 4 and beta2 glycoprotein I interaction on endothelial cells. Lupus (2014) 23(12):1302-4. doi:10.1177/0961203314536479

26. Laplante P, Fuentes R, Salem D, Subang R, Gillis MA, Hachem A, et al. Antiphospholipid antibody-mediated effects in an arterial model of thrombosis are dependent on toll-like receptor 4. Lupus (2016) 25(2):162-76. doi:10.1177/0961203315603146

27. Xia L, Xie H, Yu Y, Zhou H, Wang T, Yan J. The effects of NF-kappaB and c-Jun/AP-1 on the expression of prothrombotic and proinflammatory molecules induced by anti-beta2GPI in mouse. PLoS One (2016) 11(2):e0147958. doi:10.1371/journal.pone. 0147958

28. Miyakis S, Lockshin MD, Atsumi T, Branch DW, Brey RL, Cervera R, et al. International consensus statement on an update of the classification criteria for definite antiphospholipid syndrome (APS). J Thromb Haemost (2006) 4(2):295-306. doi:10.1111/j.1538-7836.2006.01753.x

29. Giannakopoulos B, Krilis SA. The pathogenesis of the antiphospholipid syndrome. N Engl J Med (2013) 368(11):1033-44. doi:10.1056/NEJMra1112830

30. Arachchillage DRJ, Laffan M. Pathogenesis and management of antiphospholipid syndrome. Br J Haematol (2017) 178(2):181-95. doi:10.1111/bjh.14632

31. Erkan D, Lockshin MD. Non-criteria manifestations of antiphospholipid syndrome. Lupus (2010) 19(4):424-7. doi:10.1177/0961203309360545

32. Galli M, Comfurius P, Maassen C, Hemker HC, de Baets MH, van BredaVriesman PJ, et al. Anticardiolipin antibodies (ACA) directed not to cardiolipin but to a plasma protein cofactor. Lancet (1990) 335(8705):1544-7. doi:10.1016/0140-6736(90)91374-J

33. Willis R, Pierangeli SS. Pathophysiology of the antiphospholipid antibody syndrome. Auto Immun Highlights (2011) 2(2):35-52. doi:10.1007/ s13317-011-0017-9

34. McNeil HP, Simpson RJ, Chesterman CN, Krilis SA. Antiphospholipid antibodies are directed against a complex antigen that includes a lipid-binding inhibitor of coagulation: beta 2-glycoprotein I (apolipoprotein H). Proc Natl Acad Sci U S A (1990) 87(11):4120-4. doi:10.1073/pnas.87.11.4120

35. Schwarzenbacher R, Zeth K, Diederichs K, Gries A, Kostner GM, Laggner P, et al. Crystal structure of human beta2-glycoprotein I: implications for phospholipid binding and the antiphospholipid syndrome. EMBO J (1999) 18(22):6228-39. doi:10.1093/emboj/18.22.6228

36. de Laat B, van Berkel M, Urbanus RT, Siregar B, de Groot PG, Gebbink MF, et al. Immune responses against domain I of beta(2)-glycoprotein I are driven 
by conformational changes: domain I of beta(2)-glycoprotein I harbors a cryptic immunogenic epitope. Arthritis Rheum (2011) 63(12):3960-8. doi:10.1002/art.30633

37. Agar C, van Os GM, Morgelin M, Sprenger RR, Marquart JA, Urbanus RT, et al. Beta2-glycoprotein I can exist in 2 conformations: implications for our understanding of the antiphospholipid syndrome. Blood (2010) 116(8):1336-43. doi:10.1182/blood-2009-12-260976

38. Ioannou Y, Zhang JY, Qi M, Gao L, Qi JC, Yu DM, et al. Novel assays of thrombogenic pathogenicity in the antiphospholipid syndrome based on the detection of molecular oxidative modification of the major autoantigen beta2-glycoprotein I. Arthritis Rheum (2011) 63(9):2774-82. doi:10.1002/ art.30383

39. Lackner KJ, Muller-Calleja N. Pathogenesis of the antiphospholipid syndrome revisited: time to challenge the dogma. J Thromb Haemost (2016) 14(6):1117-20. doi:10.1111/jth.13320

40. ManukyanD, Muller-Calleja N, JackelS, Luchmann K, MonnikesR, Kiouptsi K, et al. Cofactor-independent human antiphospholipid antibodies induce venous thrombosis in mice. J Thromb Haemost (2016) 14(5):1011-20. doi:10.1111/jth.13263

41. Sherer Y, Blank M, Shoenfeld Y. Antiphospholipid syndrome (APS): where does it come from? Best Pract Res Clin Rheumatol (2007) 21(6):1071-8. doi:10.1016/j.berh.2007.09.005

42. de Groot PG, de Laat B. Mechanisms of thrombosis in systemic lupus erythematosus and antiphospholipid syndrome. Best Pract Res Clin Rheumatol (2017) 31(3):334-41. doi:10.1016/j.berh.2017.09.008

43. Du VX, Kelchtermans H, de Groot PG, de Laat B. From antibody to clinical phenotype, the black box of the antiphospholipid syndrome: pathogenic mechanisms of the antiphospholipid syndrome. Thromb Res (2013) 132(3):319-26. doi:10.1016/j.thromres.2013.07.023

44. de Groot PG, Urbanus RT, Derksen RH. Pathophysiology of thrombotic APS: wheredowestand? Lupus(2012)21(7):704-7.doi:10.1177/0961203312438631

45. Pengo V, Ruffatti A, Legnani C, Testa S, Fierro T, Marongiu F, et al. Incidence of a first thromboembolic event in asymptomatic carriers of high-risk antiphospholipid antibody profile: a multicenter prospective study. Blood (2011) 118(17):4714-8. doi:10.1182/blood-2011-03-340232

46. Harvey AM, Shulman LE. Connective tissue disease and the chronic biologic false-positive test for syphilis (BFP reaction). Med Clin North Am (1966) 50(5):1271-9.

47. Goldberg SN, Conti-Kelly AM, Greco TP. A family study of anticardiolipin antibodies and associated clinical conditions. Am J Med (1995) 99(5):473-9. doi:10.1016/S0002-9343(99)80222-8

48. Mackworth-Young C, Chan J, Harris N, Walport M, Bernstein R, Batchelor R, et al. High incidence of anticardiolipin antibodies in relatives of patients with systemic lupus erythematosus. J Rheumatol (1987) 14(4):723-6.

49. Goel N, Ortel TL, Bali D, Anderson JP, Gourley IS, Smith H, et al. Familial antiphospholipid antibody syndrome: criteria for disease and evidence for autosomal dominant inheritance. Arthritis Rheum (1999) 42(2):318-27. doi:10.1002/1529-0131(199902)42:2<318::AID-ANR15>3.0.CO;2-5

50. Arnett FC, Olsen ML, Anderson KL, Reveille JD. Molecular analysis of major histocompatibility complex alleles associated with the lupus anticoagulant. J Clin Invest (1991) 87(5):1490-5. doi:10.1172/JCI115158

51. Asherson RA, Doherty DG, Vergani D, Khamashta MA, Hughes GR. Major histocompatibility complex associations with primary antiphospholipid syndrome. Arthritis Rheum (1992) 35(1):124-5. doi:10.1002/art.1780350119

52. Galeazzi M, Sebastiani GD, Tincani A, Piette JC, Allegri F, Morozzi G, et al. HLA class II alleles associations of anticardiolipin and anti-beta2GPI antibodies in a large series of European patients with systemic lupus erythematosus. Lupus (2000) 9(1):47-55. doi:10.1177/096120330000900109

53. Hashimoto H, Yamanaka K, Tokano Y, Iida N, Takasaki Y, Kabasawa K, et al. HLA-DRB1 alleles and beta 2 glycoprotein I-dependent anticardiolipin antibodies in Japanese patients with systemic lupus erythematosus. Clin Exp Rheumatol (1998) 16(4):423-7.

54. Caliz R, Atsumi T, Kondeatis E, Amengual O, Khamashta MA, Vaughan RW, et al. HLA class II gene polymorphisms in antiphospholipid syndrome: haplotype analysis in 83 Caucasoid patients. Rheumatology (Oxford) (2001) 40(1):31-6. doi:10.1093/rheumatology/40.1.31

55. Vargas-Alarcon G, Granados J, Bekker C, Alcocer-Varela J, Alarcon-Segovia D. Association of HLA-DR5 (possibly DRB1*1201) with the primary antiphospholipid syndrome in Mexican patients. Arthritis Rheum (1995) 38(9):1340-1. doi:10.1002/art.1780380925

56. Arnett FC, Thiagarajan P, Ahn C, Reveille JD. Associations of antibeta2-glycoprotein I autoantibodies with HLA class II alleles in three ethnic groups. Arthritis Rheum (1999) 42(2):268-74. doi:10.1002/1529-0131 (199902) 42:2<268::AID-ANR8>3.0.CO;2-K

57. Wilson WA, Scopelitis E, Michalski JP, Pierangeli SS, Silveira LH, Elston RC, et al. Familial anticardiolipin antibodies and C4 deficiency genotypes that coexist with MHC DQB1 risk factors. J Rheumatol (1995) 22(2):227-35.

58. Hirose N, Williams R, Alberts AR, Furie RA, Chartash EK, Jain RI, et al. A role for the polymorphism at position 247 of the beta2-glycoprotein I gene in the generation of anti-beta2-glycoprotein I antibodies in the antiphospholipid syndrome. Arthritis Rheum (1999) 42(8):1655-61. doi:10.1002/1529-0131(199908)42:8<1655::AID-ANR14>3.0.CO;2-B

59. Prieto GA, Cabral AR, Zapata-Zuniga M, Simon AJ, Villa AR, AlarconSegovia D, et al. Valine/valine genotype at position 247 of the beta2-glycoprotein I gene in Mexican patients with primary antiphospholipid syndrome: association with anti-beta2-glycoprotein I antibodies. Arthritis Rheum (2003) 48(2):471-4. doi:10.1002/art.10771

60. Hashimoto Y, Kawamura M, Ichikawa K, Suzuki T, Sumida T, Yoshida S, et al. Anticardiolipin antibodies in NZW x BXSB F1 mice. A model of antiphospholipid syndrome. J Immunol (1992) 149(3):1063-8.

61. Kita Y, Sumida T, Ichikawa K, Maeda T, Yonaha F, Iwamoto I, et al. V gene analysis of anticardiolipin antibodies from MRL-lpr/lpr mice. JImmunol (1993) 151(2):849-56.

62. Ida A, Hirose S, Hamano Y, Kodera S, Jiang Y, Abe M, et al. Multigenic control of lupus-associated antiphospholipid syndrome in a model of (NZW x BXSB) F1 mice. Eur J Immunol (1998) 28(9):2694-703. doi:10.1002/ (SICI)1521-4141(199809)28:09<2694::AID-IMMU2694>3.0.CO;2-\#

63. Papalardo E, Romay-Penabad Z, Willis R, Christadoss P, Carrera-Marin AL, Reyes-Maldonado E, et al. Major histocompatibility complex class II alleles influence induction of pathogenic antiphospholipid antibodies in a mouse model of thrombosis. Arthritis Rheumatol (2017) 69(10):2052-61. doi:10.1002/art.40195

64. Verthelyi D, Ansar Ahmed S. Characterization of estrogen-induced autoantibodies to cardiolipin in non-autoimmune mice. J Autoimmun (1997) 10(2):115-25. doi:10.1006/jaut.1996.0121

65. Cervera R, Asherson RA. Antiphospholipid syndrome associated with infections: clinical and microbiological characteristics. Immunobiology (2005) 210(10):735-41. doi:10.1016/j.imbio.2005.10.003

66. Blank M, Krause I, Fridkin M, Keller N, Kopolovic J, Goldberg I, et al. Bacterial induction of autoantibodies to beta2-glycoprotein-I accounts for the infectious etiology of antiphospholipid syndrome. JClin Invest (2002) 109(6):797-804. doi:10.1172/JCI0212337

67. Sene D, Piette JC, Cacoub P. [Antiphospholipid antibodies, antiphospholipid syndrome and viral infections]. Rev Med Interne (2009) 30(2):135-41. doi:10.1016/j.revmed.2008.05.020

68. van de Berg PJ, Heutinck KM, Raabe R, Minnee RC, Young SL, van Donselaar-van der Pant KA, et al. Human cytomegalovirus induces systemic immune activation characterized by a type 1 cytokine signature. J Infect Dis (2010) 202(5):690-9. doi:10.1086/655472

69. Kuwata T, Nishimura Y, Whitted S, Ourmanov I, Brown CR, Dang Q, et al. Association of progressive $\mathrm{CD} 4(+) \mathrm{T}$ cell decline in SIV infection with the induction of autoreactive antibodies. PLoS Pathog (2009) 5(4):e1000372. doi:10.1371/journal.ppat.1000372

70. Passam FH, Giannakopoulos B, Mirarabshahi P, Krilis SA. Molecular pathophysiology of the antiphospholipid syndrome: the role of oxidative post-translational modification of beta 2 glycoprotein I. J Thromb Haemost (2011) 9(Suppl 1):275-82. doi:10.1111/j.1538-7836.2011.04301.x

71. Petrovas C, Vlachoyiannopoulos PG, Kordossis T, Moutsopoulos HM. Anti-phospholipid antibodies in HIV infection and SLE with or without anti-phospholipid syndrome: comparisons of phospholipid specificity, avidity and reactivity with beta2-GPI. J Autoimmun (1999) 13(3):347-55. doi:10.1006/jaut.1999.0324

72. Lillicrap DP, Pinto M, Benford K, Ford PM, Ford S. Heterogeneity of laboratory test results for antiphospholipid antibodies in patients treated with chlorpromazine and other phenothiazines. Am J Clin Pathol (1990) 93(6):771-5. doi:10.1093/ajcp/93.6.771 
73. Uetrecht J. Current trends in drug-induced autoimmunity. Autoimmun Rev (2005) 4(5):309-14. doi:10.1016/j.autrev.2005.01.002

74. Del Papa N, Raschi E, Catelli L, Khamashta MA, Ichikawa K, Tincani A, et al. Endothelial cells as a target for antiphospholipid antibodies: role of antibeta 2 glycoprotein I antibodies. Am J Reprod Immunol (1997) 38(3):212-7. doi:10.1111/j.1600-0897.1997.tb00301.x

75. Proulle V, Furie RA, Merrill-Skoloff G, Furie BC, Furie B. Platelets are required for enhanced activation of the endothelium and fibrinogen in a mouse thrombosis model of APS. Blood (2014) 124(4):611-22. doi:10.1182/ blood-2014-02-554980

76. Betapudi V, Lominadze G, Hsi L, Willard B, Wu M, McCrae KR. Antibeta2GPI antibodies stimulate endothelial cell microparticle release via a nonmuscle myosin II motor protein-dependent pathway. Blood (2013) 122(23):3808-17. doi:10.1182/blood-2013-03-490318

77. Palabrica T, Lobb R, Furie BC, Aronovitz M, Benjamin C, Hsu YM, et al. Leukocyte accumulation promoting fibrin deposition is mediated in vivo by P-selectin on adherent platelets. Nature (1992) 359(6398):848-51. doi:10.1038/359848a0

78. Scapini P, Lapinet-Vera JA, Gasperini S, Calzetti F, Bazzoni F, Cassatella MA. The neutrophil as a cellular source of chemokines. Immunol Rev (2000) 177:195-203. doi:10.1034/j.1600-065X.2000.17706.x

79. Kolaczkowska E, Kubes P. Neutrophil recruitment and function in health and inflammation. Nat Rev Immunol (2013) 13(3):159-75. doi:10.1038/nri3399

80. Brinkmann V, Zychlinsky A. Neutrophil extracellular traps: is immunity the second function of chromatin? J Cell Biol (2012) 198(5):773-83. doi:10.1083/ jcb. 201203170

81. Fuchs TA, Brill A, Duerschmied D, Schatzberg D, Monestier M, Myers DD Jr, et al. Extracellular DNA traps promote thrombosis. Proc Natl Acad Sci U S A (2010) 107(36):15880-5. doi:10.1073/pnas.1005743107 Epub 2010/08/28.,

82. Gupta S, Kaplan MJ. The role of neutrophils and NETosis in autoimmune and renal diseases. Nat Rev Nephrol (2016) 12(7):402-13. doi:10.1038/ nrneph.2016.71

83. Knight JS, Meng H, Coit P, Yalavarthi S, Sule G, Gandhi AA, et al. Activated signature of antiphospholipid syndrome neutrophils reveals potential therapeutic target. JCI Insight (2017) 2(18):e93897. doi:10.1172/jci.insight.93897

84. Pierangeli SS, Liu SW, Anderson G, Barker JH, Harris EN. Thrombogenic properties of murine anti-cardiolipin antibodies induced by beta 2 glycoprotein 1 and human immunoglobulin G antiphospholipid antibodies. Circulation (1996) 94(7):1746-51. doi:10.1161/01.CIR.94.7.1746

85. Jankowski M, Vreys I, Wittevrongel C, Boon D, Vermylen J, Hoylaerts MF, et al. Thrombogenicity of beta 2-glycoprotein I-dependent antiphospholipid antibodies in a photochemically induced thrombosis model in the hamster. Blood (2003) 101(1):157-62. doi:10.1182/blood-2002-05-1310

86. Ramesh S, Morrell CN, Tarango C, Thomas GD, Yuhanna IS, Girardi G, et al. Antiphospholipid antibodies promote leukocyte-endothelial cell adhesion and thrombosis in mice by antagonizing eNOS via beta2GPI and apoER2. J Clin Invest (2011) 121(1):120-31. doi:10.1172/JCI39828

87. Arad A, Proulle V, Furie RA, Furie BC, Furie B. Beta(2)-glycoprotein-1 autoantibodies from patients with antiphospholipid syndrome are sufficient to potentiate arterial thrombus formation in a mouse model. Blood (2011) 117(12):3453-9. doi:10.1182/blood-2010-08-300715

88. Fischetti F, Durigutto P, Pellis V, Debeus A, Macor P, Bulla R, et al. Thrombus formation induced by antibodies to beta2-glycoprotein I is complement dependent and requires a priming factor. Blood (2005) 106(7):2340-6. doi:10.1182/blood-2005-03-1319

89. Shoenfeld Y, Meroni PL, Toubi E. Antiphospholipid syndrome and systemic lupus erythematosus: are they separate entities or just clinical presentations on the same scale? Curr Opin Rheumatol (2009) 21(5):495-500. doi:10.1097/ BOR.0b013e32832effdd

90. Espinola RG, Liu X, Colden-Stanfield M, Hall J, Harris EN, Pierangeli SS. E-Selectin mediates pathogenic effects of antiphospholipid antibodies. J Thromb Haemost (2003) 1(4):843-8. doi:10.1046/j.1538-7836.2003.00119.x

91. Vega-Ostertag ME, Ferrara DE, Romay-Penabad Z, Liu X, Taylor WR, ColdenStanfield M, et al. Role of p38 mitogen-activated protein kinase in antiphospholipid antibody-mediated thrombosis and endothelial cell activation. J Thromb Haemost (2007) 5(9):1828-34. doi:10.1111/j.1538-7836.2007.02680.x

92. Romay-Penabad Z, Aguilar-Valenzuela R, Urbanus RT, Derksen RH, Pennings MT, Papalardo E, et al. Apolipoprotein E receptor 2 is involved in the thrombotic complications in a murine model of the antiphospholipid syndrome. Blood (2011) 117(4):1408-14. doi:10.1182/blood-2010-07-299099

93. Lambrianides A, Carroll CJ, Pierangeli SS, Pericleous C, Branch W, Rice J, et al. Effects of polyclonal IgG derived from patients with different clinical types of the antiphospholipid syndrome on monocyte signaling pathways. J Immunol (2010) 184(12):6622-8. doi:10.4049/jimmunol.0902765

94. Meroni PL, Borghi MO, Raschi E, Tedesco F. Pathogenesis of antiphospholipid syndrome: understanding the antibodies. Nat Rev Rheumatol (2011) 7(6):330-9. doi:10.1038/nrrheum.2011.52

95. Reynaud Q, Lega JC, Mismetti P, Chapelle C, Wahl D, Cathebras P, et al. Risk of venous and arterial thrombosis according to type of antiphospholipid antibodies in adults without systemic lupus erythematosus: a systematic review and meta-analysis. Autoimmun Rev (2014) 13(6):595-608. doi:10.1016/j. autrev.2013.11.004

96. de Laat HB, Derksen RH, Urbanus RT, Roest M, de Groot PG. Beta2glycoprotein I-dependent lupus anticoagulant highly correlates with thrombosis in the antiphospholipid syndrome. Blood (2004) 104(12):3598-602. doi:10.1182/blood-2004-03-1107

97. Pengo V, Ruffatti A, Tonello M, Cuffaro S, Banzato A, Bison E, et al. Antiphospholipid syndrome: antibodies to domain 1 of beta2-glycoprotein 1 correctly classify patients at risk. J Thromb Haemost (2015) 13(5):782-7. doi: $10.1111 /$ jth. 12865

98. Pengo V, Ruffatti A, Legnani C, Gresele P, Barcellona D, Erba N, et al. Clinical course of high-risk patients diagnosed with antiphospholipid syndrome. J Thromb Haemost (2010) 8(2):237-42. doi:10.1111/j.1538-7836.2009. 03674.x

99. Banzato A, Pozzi N, Frasson R, De Filippis V, Ruffatti A, Bison E, et al. Antibodies to domain I of beta(2)glycoprotein I are in close relation to patients risk categories in antiphospholipid syndrome (APS). Thromb Res (2011) 128(6):583-6. doi:10.1016/j.thromres.2011.04.021

100. de Laat B, Pengo V, Pabinger I, Musial J, Voskuyl AE, Bultink IE, et al. The association between circulating antibodies against domain I of beta2-glycoprotein I and thrombosis: an international multicenter study. J Thromb Haemost (2009) 7(11):1767-73. doi:10.1111/j.1538-7836.2009.03588.x

101. Pericleous C, Ruiz-Limon P, Romay-Penabad Z, Marin AC, Garza-Garcia A, Murfitt L, et al. Proof-of-concept study demonstrating the pathogenicity of affinity-purified IgG antibodies directed to domain I of beta2-glycoprotein I in a mouse model of anti-phospholipid antibody-induced thrombosis. Rheumatology (Oxford) (2015) 54(4):722-7. doi:10.1093/rheumatology/ keu360

102. Branch DW, Dudley DJ, Mitchell MD, Creighton KA, Abbott TM, Hammond $\mathrm{EH}$, et al. Immunoglobulin $\mathrm{G}$ fractions from patients with antiphospholipid antibodies cause fetal death in BALB/c mice: a model for autoimmune fetal loss. Am J Obstet Gynecol (1990) 163(1 Pt 1):210-6. doi:10.1016/ S0002-9378(11)90700-5

103. Rand JH, Wu XX, Quinn AS, Taatjes DJ. The annexin A5-mediated pathogenic mechanism in the antiphospholipid syndrome: role in pregnancy losses and thrombosis. Lupus (2010) 19(4):460-9. doi:10.1177/0961203310361485

104. Stone S, Pijnenborg R, Vercruysse L, Poston R, Khamashta MA, Hunt BJ, et al. The placental bed in pregnancies complicated by primary antiphospholipid syndrome. Placenta (2006) 27(4-5):457-67. doi:10.1016/j. placenta.2005.04.006

105. Meroni PL, Tedesco F, Locati M, Vecchi A, Di Simone N, Acaia B, et al. Anti-phospholipid antibody mediated fetal loss: still an open question from a pathogenic point of view. Lupus (2010) 19(4):453-6. doi:10.1177/ 0961203309361351

106. Holers VM, Girardi G, Mo L, Guthridge JM, Molina H, Pierangeli SS, et al. Complement C3 activation is required for antiphospholipid antibodyinduced fetal loss. J Exp Med (2002) 195(2):211-20. doi:10.1084/jem. 200116116

107. Girardi G, Berman J, Redecha P, Spruce L, Thurman JM, Kraus D, et al. Complement C5a receptors and neutrophils mediate fetal injury in the antiphospholipid syndrome. J Clin Invest (2003) 112(11):1644-54. doi:10.1172/ JCI200318817

108. Berman J, Girardi G, Salmon JE. TNF-alpha is a critical effector and a target for therapy in antiphospholipid antibody-induced pregnancy loss. J Immunol (2005) 174(1):485-90. doi:10.4049/jimmunol.174.1.485

109. Girardi G, Yarilin D, Thurman JM, Holers VM, Salmon JE. Complement activation induces dysregulation of angiogenic factors and causes fetal rejection 
and growth restriction. J Exp Med (2006) 203(9):2165-75. doi:10.1084/ jem.20061022

110. Salmon JE, Girardi G. Theodore E. Woodward Award: antiphospholipid syndrome revisited: a disorder initiated by inflammation. Trans Am Clin Climatol Assoc (2007) 118:99-114.

111. Girardi G, Redecha P, Salmon JE. Heparin prevents antiphospholipid antibody-induced fetal loss by inhibiting complement activation. Nat Med (2004) 10(11):1222-6. doi:10.1038/nm1121

112. Cavazzana I, Manuela N, Irene C, Barbara A, Sara S, Orietta BM, et al. Complement activation in anti-phospholipid syndrome: a clue for an inflammatory process? J Autoimmun (2007) 28(2-3):160-4. doi:10.1016/j. jaut.2007.02.013

113. Martinez de la Torre Y, Buracchi C, Borroni EM, Dupor J, Bonecchi R, Nebuloni M, et al. Protection against inflammation- and autoantibody-caused fetal loss by the chemokine decoy receptor D6. Proc Natl Acad Sci U S A (2007) 104(7):2319-24. doi:10.1073/pnas.0607514104

114. Pierangeli SS, Chen PP, Raschi E, Scurati S, Grossi C, Borghi MO, et al. Antiphospholipid antibodies and the antiphospholipid syndrome: pathogenic mechanisms. Semin Thromb Hemost (2008) 34(3):236-50. doi:10.1055/ s-0028-1082267

115. Di Simone N, Castellani R, Caliandro D, Caruso A. Antiphospholid antibodies regulate the expression of trophoblast cell adhesion molecules. Fertil Steril (2002) 77(4):805-11. doi:10.1016/S0015-0282(01)03258-7

116. Francis J, Rai R, Sebire NJ, El-Gaddal S, Fernandes MS, Jindal P, et al. Impaired expression of endometrial differentiation markers and complement regulatory proteins in patients with recurrent pregnancy loss associated with antiphospholipid syndrome. Mol Hum Reprod (2006) 12(7):435-42. doi:10.1093/molehr/gal048

117. Tong M, Johansson C, Xiao F, Stone PR, James JL, Chen Q, et al. Antiphospholipid antibodies increase the levels of mitochondrial DNA in placental extracellular vesicles: alarmin-g for preeclampsia. Sci Rep (2017) 7(1):16556. doi:10.1038/s41598-017-16448-5

118. de Groot PG, Urbanus RT. Cellular signaling by antiphospholipid antibodies. J Thromb Haemost (2014) 12(5):773-5. doi:10.1111/jth.12540

119. Brandt KJ, Fickentscher C, Boehlen F, Kruithof EK, de Moerloose P. NF-kappaB is activated from endosomal compartments in antiphospholipid antibodies-treated human monocytes. J Thromb Haemost (2014) 12(5): 779-91. doi:10.1111/jth.12536

120. Canaud G, Bienaime F, Tabarin F, Bataillon G, Seilhean D, Noel LH, et al. Inhibition of the mTORC pathway in the antiphospholipid syndrome. $N$ Engl J Med (2014) 371(4):303-12. doi:10.1056/NEJMoa1312890

121. Xia L, Zhou H, Wang T, Xie Y, Wang T, Wang X, et al. Activation of mTOR is involved in anti-beta2GPI/beta2GPI-induced expression of tissue factor and IL-8 in monocytes. Thromb Res (2017) 157:103-10. doi:10.1016/j. thromres.2017.05.023

122. Pierangeli SS, Girardi G, Vega-Ostertag M, Liu X, Espinola RG, Salmon J. Requirement of activation of complement $\mathrm{C} 3$ and $\mathrm{C} 5$ for antiphospholipid antibody-mediated thrombophilia. Arthritis Rheum (2005) 52(7):2120-4. doi:10.1002/art.21157

123. Ritis K, Doumas M, Mastellos D, Micheli A, Giaglis S, Magotti P, et al. A novel C5a receptor-tissue factor cross-talk in neutrophils links innate immunity to coagulation pathways. J Immunol (2006) 177(7):4794-802. doi:10.4049/ jimmunol.177.7.4794

124. Romay-Penabad Z, Carrera Marin AL, Willis R, Weston-Davies W, Machin S, Cohen H, et al. Complement C5-inhibitor rEV576 (coversin) ameliorates in-vivo effects of antiphospholipid antibodies. Lupus (2014) 23(12):1324-6. doi:10.1177/0961203314546022

125. Robertson N, Rappas M, Dore AS, Brown J, Bottegoni G, Koglin M, et al. Structure of the complement C5a receptor bound to the extra-helical antagonist NDT9513727. Nature (2018) 553(7686):111-4. doi:10.1038/ nature25025
126. Breen KA, Seed P, Parmar K, Moore GW, Stuart-Smith SE, Hunt BJ. Complement activation in patients with isolated antiphospholipid antibodies or primary antiphospholipid syndrome. Thromb Haemost (2012) 107(3):423-9. doi:10.1160/TH11-08-0554

127. Arachchillage DR, Mackie IJ, Efthymiou M, Chitolie A, Hunt BJ, Isenberg DA, et al. Rivaroxaban limits complement activation compared with warfarin in antiphospholipid syndrome patients with venous thromboembolism. J Thromb Haemost (2016) 14(11):2177-86. doi:10.1111/jth.13475

128. Oku K, Atsumi T, Bohgaki M, Amengual O, Kataoka H, Horita T, et al. Complement activation in patients with primary antiphospholipid syndrome. Ann Rheum Dis (2009) 68(6):1030-5. doi:10.1136/ard.2008. 090670

129. Lonze BE, Singer AL, Montgomery RA. Eculizumab and renal transplantation in a patient with CAPS. N Engl J Med (2010) 362(18):1744-5. doi:10.1056/ NEJMc0910965

130. Shapira I, Andrade D, Allen SL, Salmon JE. Brief report: induction of sustained remission in recurrent catastrophic antiphospholipid syndrome via inhibition of terminal complement with eculizumab. Arthritis Rheum (2012) 64(8):2719-23. doi:10.1002/art.34440

131. Ostertag MV, Liu X, Henderson V, Pierangeli SS. A peptide that mimics the Vth region of beta-2-glycoprotein I reverses antiphospholipid-mediated thrombosis in mice. Lupus (2006) 15(6):358-65. doi:10.1191/0961203306lu2315oa

132. de la Torre YM, Pregnolato F, D’Amelio F, Grossi C, Di Simone N, Pasqualini F, et al. Anti-phospholipid induced murine fetal loss: novel protective effect of a peptide targeting the beta2 glycoprotein I phospholipid-binding site. Implications for human fetal loss. J Autoimmun (2012) 38(2-3):J209-15. doi:10.1016/j.jaut.2011.11.009

133. Ulrich V, Konaniah ES, Lee WR, Khadka S, Shen YM, Herz J, et al. Antiphospholipid antibodies attenuate endothelial repair and promote neointima formation in mice. JAm Heart Assoc (2014) 3(5):e001369. doi:10.1161/JAHA.114.001369

134. Ioannou Y, Romay-Penabad Z, Pericleous C, Giles I, Papalardo E, Vargas G, et al. In vivo inhibition of antiphospholipid antibody-induced pathogenicity utilizing the antigenic target peptide domain I of beta2-glycoprotein I: proof of concept. J Thromb Haemost (2009) 7(5):833-42. doi:10.1111/ j.1538-7836.2009.03316.x

135. Kolyada A, Porter A, Beglova N. Inhibition of thrombotic properties of persistent autoimmune anti- $\beta 2 \mathrm{GPI}$ antibodies in the mouse model of antiphospholipid syndrome. Blood (2014) 123(7):1090-7. doi:10.1182/ blood-2013-08-520882

136. Lai ZW, Hanczko R, Bonilla E, Caza TN, Clair B, Bartos A, et al. $\mathrm{N}$-acetylcysteine reduces disease activity by blocking mammalian target of rapamycin in $\mathrm{T}$ cells from systemic lupus erythematosus patients: a randomized, double-blind, placebo-controlled trial. Arthritis Rheum (2012) 64(9):2937-46. doi:10.1002/art.34502

137. Zheng W, Warner R, Ruggeri R, Su C, Cortes C, Skoura A, et al. PF-1355, a mechanism-based myeloperoxidase inhibitor, prevents immune complex vasculitis and anti-glomerular basement membrane glomerulonephritis. J Pharmacol Exp Ther (2015) 353(2):288-98. doi:10.1124/jpet.114.221788

Conflict of Interest Statement: The authors declare that the research was conducted in the absence of any commercial or financial relationships that could be construed as a potential conflict of interest.

Copyright $\odot 2018$ Radic and Pattanaik. This is an open-access article distributed under the terms of the Creative Commons Attribution License (CC BY). The use, distribution or reproduction in other forums is permitted, provided the original author(s) and the copyright owner are credited and that the original publication in this journal is cited, in accordance with accepted academic practice. No use, distribution or reproduction is permitted which does not comply with these terms. 